\title{
ПОНЯТТЯ «СТИЛЬ» І «ДИСКУРС» В ІНТЕРПРЕТАЦІЙНИХ ПАРАДИГМАХ СУЧАСНОЇ ЛІНГВІСТИЧНОЇ ДУМКИ
}

У статті проаналізовано погляди украӥнських і зарубіжних мовознавців на поняття «стиль» та «дискурс». Акиентовано напрями наукової кониептуалізацї поняття «стиль» в українській, російській, франиузькій, німецькій лінгвістичній думці. Проаналізовано особливості розуміння поняття стилю у зв'язку з дискурсом. Окреслено критерії класифікації функиійних стилів. Розглянуто співвідношення "стилю» й «дискурсу» в сучасному мовознавстві (взаємодоповнення, взаємовиняток, взаємозаміна чи індиферентність та нерозрізнення).

Ключові слова: мова, стиль, функиій мови, функційний стиль, функційно-стилістична диференціація, дискурс.

Humeniak V. The Concept of "Style" and "Discourse" in the Interpretive Paradigms of Modern Linguistic Thought. For modern linguistics, cognitive issues of importance for the study of the features of functional implementation of language in various spheres of social life are prominent. Recently, linguists have been considering style in relation to discourse. Despite the theoretical and methodological closeness of discourse analysis and functional stylistics, these concepts cannot be identified. Therefore, it seems necessary to systematize the approaches developed in modern linguistics to define and interpret the concepts of "style" and "discourse", to find out the specific relation of these concepts, to distinguish their common and distinguishing features.

The article analyzes the directions of scientific conceptualization of the concept of "style" in Ukrainian, Russian, French, German linguistic thought. Language styles are formed in certain functionally specialized spheres of communication that correlate with certain forms of social consciousness (scientific, artistic, philosophical, religious, political, economic, legal, etc.). Purpose, communication tasks, functional load, the appointment of an appropriate form of social consciousness, are the extralingual basis of functional styles. The same style can be distinguished on the basis of different speech functions, and the same social function can be a differential feature for different styles.

The interpretative paradigm of "style" and "discourse" in modern linguistics is realized in the aspects of their complementarity, mutual exclusion, interchangeability or indifference and indistinguishability. Both style and discourse are represented through text in its communication with the sphere of communication. Considering style and discourse as independent, non-synonymous concepts denoting phenomena requiring excellent research methods, we emphasize the importance of a correct and balanced combination of functional-stylistic approach and methods of discourse 
analysis of texts with the purpose of their holistic and various aspect characteristics in the structural and aspect characteristics.

Key words: language, style, functions of language, functional style, functionalstylistic differentiation, discourse.

\section{Вступ}

Для сучасної лінгвостилістики важливу пізнавальну значущість мають питання, пов’язані з вивченням особливостей функційної реалізації мови в різних сферах суспільного життя. Важливим видається характеристика понять «стиль» $\mathrm{i}$ «дискурс» як необхідної передумови розв’язання низки конкретних завдань, підпорядкованих з'ясуванню закономірностей формування законодавчого підстилю періоду початку XX століття.

Попри існування великої кількості наукових праць вітчизняних (Ю. Арешенков, І. Білодід, Л. Булаховський, С. Єрмоленко, А. Коваль, М. Пилинський, О. Пономарів, В. Русанівський, Л. Ставицька, І. Чередниченко, Л. Шевченко та ін.) і зарубіжних мовознавців (Ш. Баллі, В. Виноградов, Г. Винокур, Б. Гавранек, І. Гальперін, С. Гайда, М. Кожина, Д. Шмельов та ін.), що присвячені аналізу проблем функційної стилістики, дискусійною залишається низка питань, зокрема термінологічне забезпечення означеної теми, критерії класифікації функційних стилів і їх кількість.

Останнім часом мовознавці розглядають стиль у зв'язку з дискурсом. Базуючись на класичному визначенні поняття «дискурс» як «тексту, узятого в подієвому аспекті; мовлення, що розглядається як цілеспрямована соціальна дія, як компонент, що бере участь у взаємодії людей і механізмах їхньої свідомості (когнітивних процесах)» (Арутюнова, 1990: 136-137), дослідники демонструють різноманітність підходів до тлумачення стилю й дискурсу, наголошуючи на їх багатовимірності та складності (праці Т. Воронцової (2015), Н. Клушиної (2011, 2016), М. Кожиної (2008), Т. Крисанової (2016), А. Негришева (2014), О. Орлової (2013), В. Чернявської $(2011,2014)$, I. Шевченко (2012)).

Відтак видається необхідним систематизувати вироблені в сучасному мовознавстві підходи до визначення й тлумачення понять «стиль» i «дискурс», з’ясувати специфіку співвідношення цих понять, виділити спільні й відмінні риси, окреслити критерії класифікації функційних стилів. Саме ці позиції окреслюють мету розвідки. 


\section{Методи та методики дослідження}

Основу загального методологічного й теоретичного інструментарію роботи становить діалектичний метод пізнання сутності понять «стиль» і «дискурс». Крім діалектичного методу, застосовано також формально-логічні методи аналізу і синтезу, що використовувалися в процесі з'ясування змісту понять дискурс, стиль, функційний стиль, функційний різновид, підстиль офіційно-ділового стилю. Серед емпіричних методів дослідження застосовували описовий і порівняльний методи.

\section{Результати та дискусії}

Хрестоматійним для східнослов'янської лінгвістики $є$ поняття «стиль», запропоноване В. Виноградовим у середині ХХ століття: «Стиль - це суспільно усвідомлена й функціонально зумовлена, внутрішньо об’єднана сукупність прийомів вживання, відбору й поєднання засобів мовного спілкування у сфері тієї чи тієї загальнонародної, загальнонаціональної мови, співвідносна з іншими такими ж способами вираження, що слугують для інших цілей, виконують інші функції в мовній суспільній практиці поданого народу» (Виноградов, 1955: 73). Продовжує традицію виноградівського розуміння стилю М. Кожина, виокремлюючи вслід за дослідником такі ознаки стилю, як функційно-соціальна спеціалізація мовлення, його зв'язок зі свідомістю, детермінованість сферою спілкування. На відміну від В. Виноградова, дослідниця не зводить стиль до сукупності прийомів використання засобів мовлення, а розглядає його ширше, у зв'язку із суспільною діяльністю й певною формою свідомості загалом. Згідно з визначенням М. Кожиної, функційний стиль розуміємо як «своєрідний характер мовлення, що відповідає певній сфері суспільної діяльності й співвідносній з нею формі свідомості, створений особливостями функціонування в цій сфері мовних засобів та специфічною мовленнєвою організацією, яка утворює ії стилістичне забарвлення» (Кожина, 2006: 146). Таким чином стиль усвідомлюється як мовлення в суспільному антропологічному вимірі, що пов'язано з розумінням мови не лише як певної системи знаків, а й як засобу мисленнєвомовленнєвої діяльності.

Антропоцентризм, властивий для лінгвістичних студій останнього часу, помітно вплинув на аспекти аналізу проблем стилю. Зв'язок 
мови з мисленням, що виявляє свою специфіку в різних сферах мовної діяльності, знаходить своє подальше обгрунтування в працях С. Єрмоленко. На думку дослідниці, стиль - це «різновид творчої мовної діяльності, тип мовомислення, мовної поведінки в різних колективно усвідомлених ситуаціях спілкування, дотримання умов комунікації в конкретних сферах культури. У центрі розуміння динамічної моделі стилю - людина, яка і породжує, і сприймає (декодує) стильові різновиди мови (Єрмоленко, 2016: 22-40). Зауважимо, що науковці, зокрема представники Празької лінгвістичної школи (В. Матезіус, Б. Трнка, Й. Вахек, Б. Гавранек, М. Трубецькой, Р. Якобсон), уже давно відзначали вплив людського чинника на формування стилю. В. Матезіус зауважував: «Ситуація, що визначає стиль, містить три найважливіші фактори: мовний матеріал, особистість мовця та мету, що стоїть перед ним» (Матезіус, 1967). Тому мета, завдання комунікації, функційне навантаження, призначення відповідної форми суспільної свідомості, особливості змісту, - усе це становить екстралінгвістичну основу функційних стилів. Отже, мовні стилі формуються в певних функційно спеціалізованих сферах спілкування, співвідносних з певними формами суспільної свідомості (науковою, мистецькою, філософською, релігійною, політичною, економічною, правовою та ін.).

В. Виноградов виокремлює такі найважливіші функції мови, як спілкування, повідомлення й вплив. Відповідно до функцій автор виділяв шість стилів: ужитково-побутовий (функція спілкування), ужитково-діловий, офіційно-документальний, науковий (функція повідомлення, інформування), публіцистичний, художньо-белетристичний (функція впливу) (Виноградов, 1963: 6).

Л. Лисейко вирізняє дещо інші функції: комунікативну, робочу технічну, теоретично технічну, естетичну, три з яких пропонує інтерпретувати як інформативно-комунікативні, а четверту переважно естетичною. Відповідно до цих функцій виокремлює чотири функційні стилі: розмовний, ділового спілкування, науковий, поетичну мову (Лисейко, 2013: 81-84).

У вітчизняній стилістиці традиційно виділяють п’ять основних функційних стилів сучасної української літературної мови - науковий, офіційно-діловий, публіцистичний, розмовний і художній. Порівняльний аналіз класифікаційних характеристик функційних стилів, запропонованих мовознавцями С. Єрмоленко (2016), 
А. Коваль (1970), О. Пономаревим (2000), О. Проценком (2013), засвідчив відсутність жорсткого однозначного зв'язку між функцією мови й стилем.

Таблиця 1

\begin{tabular}{|l|l|}
\hline \multicolumn{1}{|c|}{ Стиль } & \multicolumn{1}{|c|}{ Функція } \\
\hline Науковий & $\begin{array}{l}\text { Iнформативна (А. Коваль, О. Проценко) } \\
\text { Повідомлення (О. Пономарів) } \\
\text { Пізнавально-результативна (С. Єрмоленко) }\end{array}$ \\
\hline $\begin{array}{l}\text { Офіцій- } \\
\text { но-діло- } \\
\text { вий }\end{array}$ & $\begin{array}{l}\text { Повідомлення (О. Пономарів) } \\
\text { Інформативно-рольова, дидактична (С. Єрмоленко) } \\
\text { Регулятивна (О. Проценко) }\end{array}$ \\
\hline $\begin{array}{l}\text { Публіцис- } \\
\text { тичний }\end{array}$ & $\begin{array}{l}\text { Функція формування громадської думки (А. Коваль, О. Проценко) } \\
\text { Впливу (О. Пономарів) } \\
\text { Цілеспрямованого впливу комуніканта на комуніканта (С. Єрмоленко) }\end{array}$ \\
\hline $\begin{array}{l}\text { Розмов- } \\
\text { ний }\end{array}$ & $\begin{array}{l}\text { Спілкування (О. Пономарів) } \\
\text { Пізнавально-контактна (С. Єрмоленко) } \\
\text { Контактна (О. Проценко) }\end{array}$ \\
\hline Художній & $\begin{array}{l}\text { Комунікативна, естетична (А. Коваль) } \\
\text { Впливу (О. Пономарів) } \\
\text { Естетична з настановою на семантичну самодостатність тексту (С. Єр- } \\
\text { моленко) } \\
\text { Естетична (О. Проценко) }\end{array}$ \\
\hline
\end{tabular}

Таким чином, той самий стиль може виокремлюватися на основі різних функцій мовлення, а та сама суспільна функція може бути диференційною ознакою для різних стилів (як критерій класифікації функціональних стилів сучасної української літературної мови).

У контексті зауваження щодо неусталеності критеріїв виокремлення стилів звернімо увагу на наповнення книжного й розмовного стилів, до якого вдаються автори посібника «Стилістика англійської мови і дискурсивний аналіз», які класифікують функціональні стилі на книжні (bookish styles) й розмовні (colloquial styles). Група книжних стилів охоплює стиль офіційних документів (style of official documents), стиль наукової прози (style of scientific prose), газетний стиль (newspaper style), публіцистичний стиль (publicistic style) і белетристичний стиль (belletristic style). До групи розмовних стилів належать літературний розмовний стиль (literary colloquial style), неформальний розмовний стиль (informal colloquial style) і нестандартний стиль мовлення (substandard speech style) (Єфімов, Ясінецька, 2004: 17). 
Учені Лейпцизької лінгвістичної школи (А. Лескін, К. Браугман, Г. Остгоф, Б. Дельбрюг, Г. Пауль та ін.) беруть до уваги існування різних сфер функціонування мови й виділяють такі стилі: розмовно-побутовий (нім. Still des Alltagsverkehrs, Still der Alltagsrede), офіційний стиль (нім. Amtsstil), науковий стиль (нім. wissenschaftlicher Stil), зауважуючи про суперечливе виділення стилю преси й публіцистики (нім. Stil der Presse und Publizistik) з одного боку, та стилю художньої літератури (нім. Stil der schöngeistigen Literatur) (Fleischer, Michel, 1977: 251). Сучасні німецькі вчені, розгядаючи диференціацію мовних засобів, використовують термін «мова» (нім. Sprache). Г.-В. Еромс виділяє мову повсякденного спілкування (Die Alltagssprache), мову науки (Die Wissenschaftssprache), мову офіційного спілкування (Die Öffentliche Kommunikation), мову засобів масової комунікації (Die Sprache der Medien), мову навчання (Die Sprache der Unterweisung), мову літератури (Die literarische Sprache), мову релігії (Die sakrale Sprache) й мову реклами (Die Werbungssprache) (Eroms, 2008).

Якщо традиційна стилістика зосереджувала свою увагу на описі стилістичних ресурсів мови, що властиві різним рівням мовної системи, то на межі XX-XXI ст. відбувається зміна пошукової парадигми, «коли реєстр мовних одиниць та їх прогнозованих (чи спостережених як типова модель у тексті) реалізацій у комунікації науково трансформується в інших підходах - аргументації екстра- й інтралінгвальних мотивацій стилю, пізнання його системних параметрів, закономірностей добору, спеціалізації та використання мовних одиниць у функціональному стилі, інтенцій мовних знаків, їх текстових реалізацій як вербалізованої свідомості особистості та (що особливо важливо) соціуму» (Шевченко, 2017: 13). Звідси й питання виникнення нових жанрових / функційних різновидів стилів у зв'язку з виділенням нових сфер використання мови і сформованих відповідно до їх спеціалізації нових напрямів науки. Базову класифікацію функційних стилів дослідники пропонують доповнити конфесійним стилем, епістолярним, ораторським й інформаційним стилями, говорять про стиль масмедіа (медіастиль), стиль реклами, стиль політики, стиль інтернету, що раніше розглядалися в межах публіцистичного стилю, а сьогодні отримали особливе суспільне значення.

Крім поняття «стиль», як було відзначено вище, сучасне мовознавство активно послуговується іншим поняттям - «дискурс». 
Із цього приводу Н. Клушина зазначає: «На наш погляд, домінування терміна дискурс - яскравий показник зміни наукової парадигми в сучасній лінгвістиці: від системного підходу у вивченні мови (коли мова розглядається як система систем) до комунікативного дослідження лінгвістичних феноменів» (Клушина, 2011). Поряд з функційною, історичною, структурною, зіставною формується стилістика комунікативна. Антропоцентризація зумовлює формування лінгвістичної проблематики, вивчення мови в діяльнісному аспекті. Діяльнісний характер, процесуальність, динамізм, діалогічність, мовленнєва системність, екстралінгвістична обумовленість тексту як визначальні принципи його організації сформульовані ще в концепції тексту М. Кожиної, яка була за своєю суттю концепцією дискурсу, не активованим був лише сам термін «дискурс». Як зазначає Ю. Степанов, введення термінопоняття «дискурс» було пов'язане з необхідністю заповнити відсутність в англосаксонській традиції поняття «функційний стиль»: «Причина того, що при живому терміні «функційний стиль» потрібен був інший - «дискурс», полягала в особливостях національних лінгвістичних шкіл, а не в предметі. <..> В англосаксонській традиції раніше не було нічого подібного насамперед тому, що не було стилістики як особливої галузі мовознавства. Англосаксонські лінгвісти підійшли до того самого предмета, так би мовити, поза традицією - як до особливостей текстів. «Дискурс» у їхньому розумінні спочатку означав саме тексти в їхній текстовій даності й у їхніх особливостях» (Степанов, 1995: 35). Проте, незважаючи на теоретикометодологічну близькість аналізу дискурсу й функційної стилістики, ці поняття не можна ототожнювати.

Об’єктом вивчення у функційній стилістиці є стиль, а в комунікативній стилістиці - дискурс в його сучасному розумінні. Г. Кривенко виділяє такі тенденції визначення дискурсу як об'єкта лінгвістичного дослідження: по-перше, терміном дискурс номінують поняття, які $€$ подібними або суміжними, близькими або кардинально протилежними, які доповнюють або виключають одне одного; по-друге, терміном дискурс невиправдано замінюють інші, узвичаєні терміни, як-от: текст, стиль, жанр, мовлення, мова, ситуація, дискусія, сфера спілкування тощо (Кривенко, 2017: 167).

Розглядаючи особливості французької школи аналізу дискурсу й російської школи функційної стилістики, науковці наголошують 
на подібності ознак дискурсу та функційного стилю, насамперед у функційно-комунікативному плані. Дискурс безумовно пов'язаний з функційним стилем. За словами Н. Арутюнової, «непрямі відношення пов'язують теорію дискурсу з риторикою й різними версіями вчення про функційні стилі». Термін «дискурс» (фр. discours - мовлення, англ. discourse), як зазначає дослідниця, становить собою «зв'язний текст у сукупності з екстралінгвістичними - прагматичними, соціокультурними, психологічними та ін. факторами» (Арутюнова, 1990: 136-137).

Заслуговують на увагу погляди вчених на стиль як на складник дискурсу. У статті «Від стилю до дискурсу: новий поворот у лінгвістиці» Н. Клушина зазначає: «Оскільки стиль - це запропонована в межах літературної мови модель успішної соціальної комунікації, яка регламентується набором еталонних рис (норми стилю), то стиль стає обов'язковою формою реалізації авторського повідомлення адресату. Таким чином, стиль стає складником дискурсу» (Клушина, 2011: 34). Пізніше авторка висловлює іншу думку щодо співвідношення й взаємодії стилю та дискурсу: «Дискурс - це сукупність/система текстів. Стиль - це і сукупність текстів (система функційних стилів), i ïx відмінна риса. Тобто стиль може розглядатися і як система, і як іманентна ознака/характеристика системи. Стиль організує структурну зв’язність системи і надає цілісну інформацію про неї» (Клушина, 2016: 82). Дослідниця наголошує на тому, що ці феномени не виключають один одного, не дублюють, а взаємодоповнюють. Таку саму думку на природу цих понять обстоює і Т. Воронцова, зазначаючи, що функційна стилістика й дискурсологія є взаємодоповнювальними напрямами в сучасній лінгвістичній парадигмі (Воронцова, 2015: 71).

Деякі дослідники сприймають дискурс як різновид стилю або підстилю, використовуючи паралельно чи замість поняття «функційний стиль» [Моргун, 2002; Фролов, Моргун, 2004). Іноді навіть у межах одного визначення поняття дискурс розглядають і як функційно-стильовий різновид, і як стиль: «Українська лінгвістична думка акцентує увагу на сакральному дискурсі як функціонально-стильовому різновиді, що обслуговує здебільшого християнську релігійну течію (переважно православ'я), однак під впливом часу визначальні ознаки сакрального стилю модифікуються, що показує дослідження української мови в Інтернеті» (Чемеркін, 2008: 182). 
О. Орлова доходить висновку, що функційний стиль і дискурс становлять дві фундаментальні категорії, що по-різному членують комунікативний простір (Орлова, 2013: 19).

\section{Висновки}

I стиль, і дискурс репрезентуються через текст у його зв'язку зі сферою комунікації. Розглядаючи стиль і дискурс як самостійні, несинонімічні поняття, що позначають явища, які потребують відмінних методик дослідження, акцентуємо значущість коректного й виваженого поєднання функційно-стилістичного підходу та методів дискурс-аналізу текстів з метою їх цілісної різноаспектної характеристики в структурному й функційному аспектах.

Беручи до уваги неоднорідність та історичну змінність системи функційних стилів, а також особливий вплив екстралінгвальних чинників на формування стилів української мови періоду відновлення української державності 20-х років ХX століття, видається актуальним і перспективним аналізувати історію формування законодавчого підстилю української мови означеного періоду, становлення його жанрової системи в контексті розгляду власне стилетвірних і дискурсивних чинників.

\section{ЛІТЕРАТУРА}

1. Арутюнова Н. Д. Дискурс. Лингвистический энциклопедический словарь / гл. ред. В. Н. Ярцева. Москва: Сов. энциклопедия, 1990. С. 136-137. 2. Виноградов В. В. Итоги обсуждения вопросов стилистики. Вопросы языкознания. 1955. № 1. С. 60-87. 3. Виноградов В. В. Стилистика. Теория поэтической речи. Поэтика. Москва, 1963. 256 c. 4. Воронцова Т. А. Функциональная стилистика vs дискурсология или функциональная стилистика + дискурсология? Актуальные проблемы стилистики. Ежегодный международный научный журнал. 2015. № 1. С. 71-76. 5. Єрмоленко С. Бибик С., Ганжа А., Коць Т., Мех Н., Сюта Г. Українська лінгвостилістика та культура мови на межі століть: полілог поколінь. Українська мова. Київ: Інститут української мови НАН України, 2016. № 4. С. 24-40. 6. Єфімов Л. П., Ясінецька О. А. Стилістика англійської мови і дискурсивний аналіз: учбово-методичний посібник. Вінниця: Нова Книга, 2004. 240 с. 7. Клушина Н. И. От стиля к дискурсу: новый поворот в лингвистике. Язык, коммуникация и соииальная среда. Вып. 9. Воронеж, 2011. С. 26-33. 8. Клушина Н. И. Дискурс-анализ и стилистика: интегративные методы исследования медиа коммуникации. Вестник Российского университета дружбы народов. Серия «Лингвистика». 2016. Т. 20. № 4. С. 78-90. 9. Коваль А. П. Науковий стиль сучасної української літературної мови: структура наукового тексту. Київ : Вид-во Київського ун-ту, 1970. 305 с. 10. Коваль А. І. Практична стилістика сучасної української літературної мови. Київ: Вища школа, 1987. 352 с. 11. Кожина М. Н. Стиль. Стилистический 
эницилопедический словарь русского языка / под ред. М. Н. Кожиной. Москва: Флинта: Наука, 2003. С. 507-513. 12. Кожина М. Н. Классификация и внутренняя дифференциация функциональных стилей. Стилистический энциклопедический словарь / под ред. М. Н. Кожиной. Москва: Флинта: Наука, 2006. С. 146-153. 13. Кривенко Г. Л. Лінгвофілософські засади корпусної дискурсології. Південний архів. Філологічні науки: зб. наук. пр. 2017. Вип. 71. С. 166-172. 14. Крисанова Т. А. Функціональний стиль vs дискурс. Наукові записки Національного університету «Острозька академія». Серія «Філологічна». 2016. Вип. 62. С. 188-190. 15. Лисейко Л. Поняття функціонального стилю та рівні його описування. Мандрівець. 2013. № 5. С. 81-84. 16. Матезиус В. Язык и стиль. Пражский лингвистический кружок: сб. статей. Москва: Прогресс, 1967. С. 444-523. 17. Моргун Н. Л. Научный сетевой дискурс как тип текста: автореф. дис. ... канд. филол. наук. Тюмень, 2002. 20 с. 18. Негрышев А. А. Текст в перспективе стилистики и дискурс-анализа: к методологии исследования на материале новостного медиадискурса. Stylistika. 2014. Т. ХХІІІ. С. 149-161. 19. Орлова О. В. Проблема соотношения понятий стиля и дискурса в лингвистике начала XXI в. в контексте идей М. Н. Кожиной. Вестник Томского гос. ун-та. Серия «Филология». 2013. №4 (24). С. 19-25. 20. Пономарів О. Д. Стилістика сучасної української літературної мови: підручник. Тернопіль: Навчальна книга-Богдан, 2000. 248 с. 21. Проценко О. В. До проблеми вивчення функціональних стилів у вищій школі. Вісник Житомирської держ. ун-ту. 2013. Вип. 6 (72). Філологічні науки. С. 269-273. 22. Степанов Ю. С. Альтернативный мир, Дискурс, Факт и принцип Причинности. Язык и наука конца ХХ века: сб. статей. Москва: РГГУ. 1995. 432 с. 23. Стилистика русского языка: учебник / М. Н. Кожина, Л. Р. Дускаева, В. А. Салимовский. Москва: Флинта: Наука, 2008. 464 с. 24. Фролов Н. К., Моргун Н. Л. Научные стили речи в компьютерном дискурсе. Мир ПК. 2004. № 4. URL: http://frgf.utmn.ru/Nol7/textlO.htm. 25. Чемеркін С. Г. Модифікація ознак сакрального стилю в Інтернеті. Наукові записки Нац. ун-ту «Осmрозька академія». Сер «Філологічна». 2008. Вип. 10. С. 176-184. 26. Чернявская В. Е. Дискурс как фантомный объект: от текста к дискурсу и обратно? Когниция, коммуникация, дискурс. 2011. № 3. С. 86-95. 27. Чернявская В. Е. Фантомы и синдромы дискурсивной парадигмы. Вопросы когнитивной тингвистики. 2014. № 1 (038). С. 54-61. 28. Шевченко Л. І. Модерні напрямки сучасної лінгвістики: функціональний контекст. Актуальні проблеми украӥнської лінгвістики: теорія і практика. 2017. Вип. 35. С. 7-18. 29. Eroms H.-W. Stil und Stilistik. Berlin: Erich Schmidt, 2008. 255 s. 30. Fleischer W., Michel G. Stilistik der deutschen Gegenwartssprache. 2, unveränd. Aufl. Leipzig: Bibliographisches Institut, 1977. $394 \mathrm{s.}$

\section{REFERENCES}

1. Arutyunova, N. D. (1990). Diskurs [Discourse]. Lingvisticheskij énciklopedicheskij slovar' [Linguistic Encyclopedic Dictionary], (pp. 136-137). Moskva: Sov. e’nciklopediya [in Russian]. 2. Vinogradov, V. V. (1955). Itogi obsuzhdeniya voprosov stilistiki [Discussion Results of the Problem of Stylistics]. Voprosy yazykoznaniya - Questions of linguistics, 1, 6087 [in Russian]. 3. Vynogradov, V. V. (1963). Stilistika. Teoriya poe'ticheskoj rechi. Poe'tika [Stylistics. Theory of Poetic Language. Poetics.]. Moskva: Nauka [in Russian]. 4. Voroncova, T. A. (2015). Funkcional'naya stilistika vs diskursologiya ili funkcional'naya stilistika + diskursologiya? [Functional stylistics vs discourse studies or functional stylistics+discourse 
studies?]. Aktual'nye problemy stilistiki. Ezhegodnyj mezhdunarodnyj nauchnyj zhurnal Actual problems of stylistics. Annual international scientific journal, 1, 71-76 [in Russian]. 5. Yermolenko, S., Bybyk, S., Hanzha, A. , Kots, T., Mekh, N. \& Siuta, H. (2016). Ukrainska linhvostylistyka ta kultura movy na mezhi stolit: poliloh pokolin [Linguistic and language culture at the turn of the century: the polylog of generations]. Ukrainska mova - Ukrainian language, 4, 24-40 [in Ukrainian]. 6. Yefimov, L. P. \& Yasinetska, O. A. (2004). Stylistyka anhliiskoi movy $i$ dyskursyvnyi analiz [Practical stylistics of English and discursive analysis]. Vinnytsia: Nova Knyha [in English]. 7. Klushina, N. I. (2011). Ot stilya k diskursu: novyj povorot v lingvistike [From style to discourse: a new twist in linguistics]. Yazyk, kommunikaciya i social'naya sreda - Language, communication and social environment, 9, 26-33 [in Russian]. 8. Klushina, N. I. (2016). Diskurs-analiz i stilistika: integrativnye metody issledovaniya media kommunikacii [Discourse analysis and stylistics: integrative research methods of media communication]. Vestnik Rossijskogo universiteta druzhby narodov. Seriya «Lingvistika»Bulletin of the Peoples' Friendship University of Russia. Series «Linguistics», 20 (4), 78-90 [in Russian]. 9. Koval, A. P. (1970). Naukovyi styl suchasnoi ukrainskoi literaturnoi movy: struktura naukovoho tekstu [Scientific style of modern Ukrainian literary language: structure of scientific text]. Kyiv: Vyd-vo Kyivskoho un-tu [in Ukrainian]. 10. Koval, A. I. (1987). Praktychna stylistyka suchasnoi ukrainskoi literaturnoi movy [Practical Stylistics of modern Ukrainian literary language]. Kyiv: Vyshcha shkola [in Ukrainian]. 11. Kozhina, M. N. (2002). Stil'. Stilisticheskij e'nciklopedicheskij slovar' russkogo yazyka, (pp. 507-513). Moskva: Flinta; Nauka [in Russian]. 12. Kozhina, M. N. (2006) Klassifikaciya i vnutrennyaya differenciaciya funkcional'nyx stilej. Stilisticheskij e'nciklopedicheskij slovar' - Stylistic Encyclopedic Dictionary of Russian, (pp. 146-153). Moskva: Flinta: Nauka [in Russian]. 13. Kryvenko, H. L. (2017). Linhvofilosofski zasady korpusnoi dyskursolohii [Linguistic and philosophical principles of corpus discourse]. Pivdennyi arkhiv. Filolohichni nauky: $z b$. nauk. pr. - Southern Archive. Philological Sciences: Coll. Sciences, 71, 166-172 [in Ukrainian]. 14. Krysanova, T. A. (2016). Funktsionalnyi styl vs dyskurs [Functional style vs. discourse]. Naukovi zapysky Natsionalnoho universytetu «Ostrozka akademiia». Seriia «Filolohichna»Scientific notes of the Ostroh Academy National University. The Philological Series, 62, 188 190 [in Ukrainian]. 15. Lyseiko, L. (2013). Poniattia funktsionalnoho styliu ta rivni yoho opysuvannia [Functional style concepts and levels of description]. Mandrivets - Traveler, 5, 81-84 [in Ukrainian]. 16. Matezius, V. (1967) Yazyk i stil' [Language and Style]. Prazhskij lingvisticheskij kruzhok - Prague Linguistic Circle. Collection of articles. Moskva: Progress [in Russian]. 17. Morgun, N. L. (2002). Nauchnyy setevoy diskurs kak tip teksta [Scientific network discourse as a type of text]. Extended abstract of candidate's thesis. Tyumen: Tyumenskij gos. un-t [in Ukrainian]. 18. Negryshev, A. A. (2014) Tekst v perspektive stilistiki i diskurs-analiza: $\mathrm{k}$ metodologii issledovaniya na materiale novostnogo mediadiskursa [Text in the perspective of stylistics and discourse analysis: to the methodology of research on the material of a news media discourse]. Stylistyka - Stylistics, XXII, 149-161 [in Russian]. 19. Orlova, O. V. (2013). Problema sootnosheniya ponyatiy stilya i diskursa v lingvistike nachala XXI v. v kontekste idey M. N. Kozhinoy [The problem of the correlation of the concepts of style and discourse in the linguistics of the beginning of the XXI century in the context of M. N. Kozhina's ideas]. Vestnik Tomskogo gosudarstvennogo universiteta. Filologiya - Bulletin of the Tomsk State University. Philology, 4 (24), 19-25 [in Russian]. 20 Ponomariv, O. D. (2000). Stylistyka suchasnoi ukrainskoi literaturnoi movy [Stylistics 
of the Modern Ukrainian Language]. Ternopil: Navchalna knyha-Bohdan [in Ukrainian]. 21. Protsenko, O. V. (2013). Do problemy vyvchennia funktsionalnykh styliv u vyshchii shkoli [The Problem of Studying Functional Styles in Higher Education]. Visnyk Zhytomyrskoho derzhavnoho universytetu. Filolohichni nauky - Bulletin of Zhytomyr State University. Philological Sciences, 6 (72), 269-274 [in Ukrainian]. 22. Stepanov, Yu. S. (1995). Al'ternativnyj mir, Diskurs, Fakt i princip Prichinnosti [The Alternative World, Discourse, Fact and Principle of Causality]. Jazyk i nauka konca XX v. - Language and Science of the End of the XX Century. Sat. articles. Moscow: Rossiyskiy gos. gum. un-t [in Russian]. 23. Kozhina, M. N., Duskaeva, L. R., Salimovskij, V. A. (2008). Stilistika russkogo yazyka [Stylistics of the Russian language: a textbook]. Moskva: Flinta: Nauka [in Russian]. 24. Frolov, N. K., \& Morgun, N. L. (2004) Nauchnye stili rechi v kompjuternom diskurse [Scientific styles of speech in computer discourse]. Mir PK - World PC, 4. Retrieved from http://frgf.utmn.ru/Nol7/textlO.htm. [in Russian]. 25. Chemerkin, S. H. (2008). Modyfikatsiia oznak sakralnoho styliu v Interneti [Modification of the sacred style in the Internet]. Naukovi zapysky Natsionalnoho universytetu «Ostrozka akademiia»-Scientific notes of the National University "Ostrozka Academy». Ser. "Filolohichna», 10, 176-184 [in Ukrainian]. 26. Chernyavskaya, V. Ye. (2011). Diskurs kak fantomnyy ob»yekt: ot teksta $\mathrm{k}$ diskursu i obratno? [Discourse as a phantom object: from text to discourse and back?]. Kognitsiya, kommunikatsiya, diskurs - Cognition, communication, discourse, 3, 86-95 [in Russian]. 27. Chernyavskaya, V. E. (2014). Fantomy i sindromy diskursivnoy paradigm [Phantoms and syndromes of a discursive paradigm]. Voprosy kognitivnoy lingvistiki - Questions of cognitive linguistics, 1 (038), 54-61 [in Russian]. 28. Shevchenko, L. I. (2017). Moderni napriamky suchasnoi linhvistyky: funktsionalnyi kontekst [Modern directions of modern linguistics: functional context]. Aktualni problemy ukrainskoi linhvistyky: teoriia i praktyka - Topical problems of Ukrainian linguistics: theory and practice, 35, 7-18 [in Ukrainian]. 29. Eroms H.-W. (2008). Stil und Stilistik [Style and stylistics]. Berlin: Erich Schmidt [in German]. 30. Fleischer, W. \& Michel, G. (1977). Stilistik der deutschen Gegenwartssprache [Stylistics of the contemporary German language] (2nd ed.). Leipzig: Bibliographisches Institut [in German].

Гуменяк Віра Олександрівна - старший викладач кафедри державно-правових дисциплін, Харківський національний університет імені В. Н. Каразіна; площа Свободи, 4, м. Харків, 61022, Україна.

Tel.: +38-098-400-83-39

E-mail: v.gumenyak@karazin.ua

https://orcid.org/0000-0002-7260-8440

Humeniak Vira - Senior Lecturer, Department of State and Legal Disciplines, V. N. Karazin Kharkiv National University; Freedom Sqr. 4, Kharkiv, 61000, Ukraine. 